\title{
Selection of suitable media and intervals of media inoculation for culturing Tubificid worms
}

\author{
M. F. A. Mollah, K. Mosharaf and Mariom \\ Department of Fisheries Biology and Genetics, Bangladesh Agricultural University, Mymensingh-2202, Bangladesh, \\ E-mail:mariom.bau@gmail.com
}

\begin{abstract}
Tubificid worms are aquatic invertebrates, belonging to the class Oligochaeta and family Tubificidae, used as an important live food for fishes. The study was conducted to culture Tubificid worms under running water in order to develop a suitable culture media and an optimum duration of media inoculation for culturing Tubificid worms. The worms were cultured under two experiments in cemented culvert system $\left(160 \times 25 \times 10 \mathrm{~cm}^{3}\right)$ for 90 days. In the first experiment the worms were cultured in three different media designated as treatment-I, treatment-II and treatment-III. The highest yield $\left(503.39 \pm 22.98 \mathrm{mg} \mathrm{cm}^{-2}\right)$ was found at $70^{\text {th }}$ day of culture duration in the culture media containing a mixture of $35 \%$ mustard oil cake, $20 \%$ wheat bran, $25 \%$ cow-dung and $20 \%$ fine sand (treatment-III). Only $1.99 \mathrm{~kg}$ media ingredients valued BDT 29.85 were needed to yield $1 \mathrm{~kg}$ worms. In the second experiment, the worms were cultured at three different intervals of media inoculation i.e., 6, 10 and 15 days interval designated as treatment-I, treatment-II and treatment-III respectively using the media found best in the first experiment. Inoculation of media at 10 days interval showed significantly $(P<0.01)$ higher production $\left(488.94 \pm 5.60 \mathrm{mg} \mathrm{cm}^{-2}\right)$.
\end{abstract}

Keywords: Tubificid worms, Oligochaeta, Culture media, Intervals of media inoculation

\section{Introduction}

Tubificids, aquatic oligochaete, are reddish in colour found mostly in old canals and drains in towns where steady and continuous water flow exists and where large amounts of organic detritus are present. They are very small usually having a length of $3-4 \mathrm{~cm}$ (Mellanby, 1953; Jordan and Verma, 1978). They make a kind of tube for themselves out of mucus and mud particles, which then sink into the ground. The anterior part of the body settles in the tube while the rest of the body waves above the ground in a breathing movement. Majority of the aquatic species are common in the mud and debris of pools, ponds, streams, lakes and sewage canals where considerable organic matter is undergoing decay. Tubificids occur even in the depth exceeding one meter, and in the deep water of lakes there are sometimes more than 8,000 individuals $\mathrm{m}^{-2}$ (Barnes, 1966).

These worms can be one of the best quality live foods for fish because of their high food value (5575 cal $\mathrm{g}^{-1}$ dry weight; Giere and Pfannkuche, 1982). Phillips and Buhler (1979) documented significantly higher growth rates of rainbow trout (Salmo gairdneri) fed on Tubifex sp. over standard pellets. Buddington and Doroshov (1984) also showed that white sturgeon (Acipenser transmontanus) grew $40 \%$ larger when fed Tubifex sp. compared to inanimate pellets. Alam and Mollah (1988) reported significantly higher survival rate and 10 times more growth of catfish (Clarias batrachus L) larvae fed Tubificid worms over those fed formulated dry feed. The importance of Tubificid worms as a source of natural food for the fish larvae was also demonstrated for species like Clarias macrocephalus (Mollah and Tan, 1982), Clarias gariepinus (Mollah, 1991) and Channa striatus (Mollah et al., 2009). Tubificid worms have also been proved as one of the best and the cheapest live foods for various types of laboratory animals including planaria, leeches, dragonfly, aquatic beetle larvae, prawns and frogs. Ecologically, it is an important source of food for leeches, crustaceans, insects and fishes. Supplementation of Tubificid worms with factory feed increases the appetite of fish and they are considered as rare delicacy. Moreover, use of Tubificid worms as aquarium and/or ornamental fish food has been a common phenomenon in many countries including USA and USSR since long ago (Lietz, 1987). To the aquarium fish keepers the demand of these worms is considerably high. Some hatcheries also use these worms to certain extent for larvae nursing purposes. Unfortunately no suitable feed has been developed for the larvae to replace the live food to date so far as the growth and survival rate are concerned. Therefore finding a suitable culture media with optimum interval of media inoculation for culturing these worms was felt important. 


\section{Materials and Methods}

Two experiments were conducted in cemented culvert $\left(160 \times 25 \times 10 \mathrm{~cm}^{3}\right)$ system under a tin-shed to develop a suitable culture media and to assess the suitable interval of media inoculation for the production of Tubificid worms.

\section{Experiment-I: Selection of suitable culture media}

The worms were cultured in three different media (Table 1 ) to conduct a $3 \times 5$ factorial design ( 3 treatments each with 5 replications) for 90 days.

\section{Experiment-II: Determination of suitable time interval of media inoculation to the culture system}

This experiment was designed based on experiment-I and was carried out for a period of 90 days. Here the worms were cultured in three different intervals of media inoculation i.e., 6, 10 and 15 days interval under three treatments namely treatment-I, treatment-II and treatment-III.

\section{Culture procedure}

Before starting the experiment, the culture culverts were washed and cleaned thoroughly with fresh water. Water was continually supplied from the deep well to a water reservoir tank with which the culverts were connected a by stop cork. Each culvert was facilitated with inlet (porous PVC pipe of $180 \mathrm{~cm}$ long and 1 $\mathrm{cm}^{2}$ diameter) and outlet to assist in the renewal and removal of water concurrently. The required amount of locally available ingredients mentioned in Table 1 were collected and measured by a laboratory balance (TANITA, KD-160) on a proportional basis to make up $1000 \mathrm{~g}$ of media for each culvert. The ingredients were then mixed with sufficient amount of water in three different fibreglass tanks and kept for seven days for decomposition. Subsequent mixing was done every morning and evening for better mineralization. Then required amount $\left(250 \mathrm{mg} \mathrm{cm}^{-2}\right)$ of the well-mixed media was suffused to each of the culvert using a small plastic bowl.

Table 1. Combination of different media ingredients in three treatments

\begin{tabular}{|l|c|c|c|}
\hline \multirow{2}{*}{ Media ingredients } & \multicolumn{3}{|c|}{ \% of ingredients } \\
\cline { 2 - 4 } & Treatment-I & Treatment-II & Treatment-III \\
\hline Mustard oil cake & 20 & 25 & 35 \\
\hline Wheat bran & 35 & 30 & 20 \\
\hline Cow-dung & 25 & 25 & 25 \\
\hline Sand & 20 & 20 & 20 \\
\hline
\end{tabular}

Live Tubificid worms were collected from the drains of Bangladesh Agricultural University (BAU) campus, Mymensingh, Bangladesh. Collected worms were cleaned using flowing water and conditioned over $24 \mathrm{~h}$ in a flow-through system. At first, media were introduced to the culverts and water flow was adjusted at a rate of $1.24 \pm 0.33 \mathrm{~L} \mathrm{~min}^{-1}$ to keep the dissolved oxygen above $5 \mathrm{ppm}$. After $24 \mathrm{~h}$ the collected worms were inoculated at the rate of $1.25 \mathrm{mg} . \mathrm{cm}^{-2}$ (i.e., $5 \mathrm{~g} \mathrm{culvert}^{-1}$ ). The periodic supply of culture media was done once in every 10 days at $1000 \mathrm{~h}$ at the rate of $250 \mathrm{mg} \mathrm{cm}^{-2}$ in respective culverts. Water flow was stopped during media addition. Following water quality parameters were recorded during the experimental period:

a. Water temperature: Water temperature of the culture culverts was recorded with digital thermometer at $1000 \mathrm{~h}$ once in every 10 days before sampling.

b. Dissolved oxygen: Dissolved oxygen (DO) was determined with the help of Dissolved Oxygen Meter (Model: DO- 5509) once in every 10 days before sampling.

c. $\mathrm{pH}$ : Water $\mathrm{pH}$ was measured by using portable digital $\mathrm{pH}$ Meter (Model: HI 98127) once in every 10 days before sampling. 
Collection of worms from each culvert was initiated after $40^{\text {th }}$ day of the inoculation of Tubificid worms at every 10 days interval to determine the growth and multiplication as well as the production of the worms (Fig. 1) before the introduction of new media. Tubificid worms were collected by a glass tube having a diameter of $2.2 \mathrm{~cm}$ from three randomly selected places of each culvert. They were cleared from their respective media by water flow and finally parted from the unwanted particles using forceps and dropper. Separated worms were dried with tissue paper and weighed using a Matler electric balance graduated in $0.000 \mathrm{~g}$. Data were analyzed through one-way analysis of variance (ANOVA) followed by Turkey's HSD post hoc for multiple comparisons. Statistical analysis was performed using the statistical software SPSS version 11.5 with the level of significance at $P<0.05$.

\section{Results and Discussion}

\section{Experiment-I: Selection of suitable culture media}

The standing biomass of Tubificid worms in three different culture media is presented in Table 2. The highest standing biomass of $503.39 \pm 22.98 \mathrm{mg} \mathrm{cm}^{-2}$ was found in treatment-III on the $70^{\text {th }}$ experimental day where the quantity of the mustard oil cake was the highest (35\%) compared to the other treatments. The standing biomass of treatment-I was significantly $(P<0.01)$ different from those of treatment-II and treatment-III throughout the experiment except on the $70^{\text {th }}$ experimental day (Table 2). In treatment-II and treatment-III a gradual increase in standing biomass of Tubificid worms was found up to the $70^{\text {th }}$ experimental day followed by a decrease in biomass up to the end of the experimental periods (90 days). Statistical analysis by ANOVA showed that there was no significant difference $(P<0.01)$ in production between treatment-II and treatment-III, though the standing biomass of Tubificid worms in treatment-III was higher than that of treatment-II from the starting to the end of the experiment. However, treatment-I showed the same trend of increase in biomass up to the $80^{\text {th }}$ day showing a peak of $422.06 \pm 1.33 \mathrm{mg} \mathrm{cm}^{-2}$ on the $80^{\text {th }}$ experimental day followed by an abrupt decline in the biomass of $313.22 \pm 5.03 \mathrm{mg} \mathrm{cm}^{-2}$ at the $90^{\text {th }}$ day. The result showed that the standing biomass of treatment-I faced troublesome situation of lower population throughout the experimental period due to the effect of media, where the quantity of mustard oil cake was the lowest (20\%) compared to the other media.

Table 2. Standing biomass $\left(\mathrm{mg} \mathrm{cm}^{-2}\right)$ of Tubificid worms in three different treatments during 90 days experimental period (mean $\pm S D$ )

\begin{tabular}{|c|c|c|c|c|c|c|}
\hline \multirow{2}{*}{ Treatments } & \multicolumn{7}{|c|}{ Experimental period in days } \\
\cline { 2 - 7 } & 40 & 50 & 60 & 70 & 80 & 90 \\
\hline I & 115.65 & 207.92 & 295.16 & 344.83 & 422.06 & 313.22 \\
& $\pm 10.39^{\mathrm{c}}$ & $\pm 23.34^{\mathrm{b}}$ & $\pm 4.04^{\mathrm{b}}$ & $\pm 11.11^{\mathrm{b}}$ & $\pm 1.33^{\mathrm{b}}$ & $\pm 5.03^{\mathrm{a}}$ \\
\hline II & 204.46 & 300.56 & 370.44 & 450.01 & 376.90 & 265.40 \\
& $\pm 30.50^{\mathrm{b}}$ & $\pm 26.92^{\mathrm{a}}$ & $\pm 22.47^{\mathrm{a}}$ & $\pm 20.09^{\mathrm{a}}$ & $\pm 12.24^{\mathrm{a}}$ & $\pm 3.46^{\mathrm{b}}$ \\
\hline III & 280.26 & 352.45 & 426.26 & 503.39 & 404.13 & 319.19 \\
& $\pm 20.03^{\mathrm{a}}$ & $\pm 23.52^{\mathrm{a}}$ & $\pm 18.97^{\mathrm{a}}$ & $\pm 22.98^{\mathrm{a}}$ & $\pm 1.48^{\mathrm{ab}}$ & $\pm 6.51^{\mathrm{a}}$ \\
\hline
\end{tabular}

* Values with different Superscripts in a vertical column are significantly different (one way ANOVA followed by Tukey test, $P<0.01)$.

In this study the choice of media substrates containing a mixture of various ratio of mustard oil cake, wheat bran, cow-dung and fine sand for culture of Tubificid worms and the rate of media application was made on the basis of previous studies conducted by Marian and Pandian (1984) and Ahamed and Mollah (1992). A comparison of the yield of these worms indicated that the media containing $35 \%$ mustard oil cake, 20\% wheat bran, 25\% cow-dung and 20\% sand (treatment-III) was the best as it produced $503.39 \pm 22.98 \mathrm{mg} \mathrm{cm}^{-2}$ of Tubificid worms on $70^{\text {th }}$ day (Table 2). Ahamed and Mollah (1992) reported that the media containing $20 \%$ mustard oil cake, 35\% wheat bran, $25 \%$ cow-dung and $20 \%$ sand gave better production (419.4 $\mathrm{mg} \mathrm{cm}^{-2}$ ) of Tubificid worms compared to a substrate containing $75 \%$ cow-dung and $25 \%$ fine sand as indicated by Marian and Pandian (1984). However, Marian and Pandian (1984) also reported a production of $200 \mathrm{mg} \mathrm{cm}^{-2}$ worms. 
Mustard oil cake, wheat bran, soybean meal, cow-dung and sand are important media ingredients for culturing Tubificid worms. Ahamed and Mollah (1992) observed better growth when mustard oil cake and wheat bran were used as media ingredient while present study demonstrated that mustard oil cake has a definite effect on the culture of these worms, probably because of containing various nutrients like minerals and organic matter (Ahamed and Mollah, 1992). The production in treatment-I was lower due to the lower quantity of mustard oil cake in comparison to other treatments.

Fecundity of Tubifex tubifex depends on the temperature, rate of water flow and organic content of the culture media (Marian and Pandian, 1984). Sexual maturity is more rapid at a higher temperature and enough dissolved oxygen content when adequate organic carbon (especially mustard oil cake) is present in the culture media. In the present study water temperature, dissolved oxygen and $\mathrm{pH}$ of the culverts were suitable and in productive range as found by Davis (1982), Poddubnaya (1980) and Li RenXi (2001) and ranged from 24.3 to $26.5^{\circ} \mathrm{C}, 7.0$ to $7.4 \mathrm{ppm}$ and 7.1 to 7.4 respectively.

Ahamed and Mollah (1992) stated that $2.85 \mathrm{~kg}$ raw materials were required for $1 \mathrm{~kg}$ worm production against $18 \mathrm{~kg}$ and $25 \mathrm{~kg}$ cow-dung reported by Marian and Pandian (1984) and Marian et al. (1989) respectively. The present study required only $1.99 \mathrm{~kg}$ raw materials (35\% mustard oil cake, $20 \%$ wheat bran, $25 \%$ cow-dung and $20 \%$ fine sand) valued BDT 29.85 for $1 \mathrm{~kg}$ worms which proved the superiority of this media for the production of Tubificid worms compared to the previous ones.

Experiment-II: Determination of a suitable time interval of media inoculation to the culture system The standing biomass of Tubificid worms at three different intervals of media inoculation into the culverts are presented in Fig. 2. The production of the worms at three different treatments showed significant difference $(P<0.01)$ throughout the experimental period (Fig. 2). Results analyzed by ANOVA with multiple comparisons revealed that the intervals of media application into the culverts have significant effect on the growth and production of Tubificid worms. The standing biomass of treatment-II was significantly $(P<0.01)$ higher from that of treatment-III showing a peak production of $488.94 \pm 5.60 \mathrm{mg} \mathrm{cm}^{-2}$ on the $70^{\text {th }}$ experimental day (Fig. 2). In treatment-II, a gradual increase in standing biomass was spectacular up to the $70^{\text {th }}$ experimental day before showing a decline in biomass up to the end of the experimental periods (90 days). In treatment-I, the standing biomass of Tubificid worms reached peak point earlier $\left(60^{\text {th }}\right.$ experimental day) compared to other treatments. Recurrent application of media to the culverts might be responsible for this. After $60^{\text {th }}$ day abrupt falling trend of standing biomass in treatment-I indicated that higher decomposition with low dissolved oxygen might be responsible for this. The standing biomass of the worms in treatment-III reached its pinnacle later $\left(80^{\text {th }}\right.$ experimental day) compared to other treatments. This delay occurred due to 15 days interval of media application, which led to run out nutrients rapidly. Thus, the growth of Tubificid worms hampered.

The experiment for determining the suitable interval of media application to the culture system was based on the previous study conducted by Mollah and Hossain (1995). They found the highest production of $556.25 \pm 21.87 \mathrm{mg} \mathrm{cm}^{-2}$ when the media was supplied at 6 days interval compared to those supplied at 10 days and 15 days interval. In the present study, media introduction to the culverts between 6 days and 10 days interval showed little incongruity in terms of production. The production in treatment-I and treatmentII were higher than that of treatment-III. The culverts in treatment-I and treatment-II were rich in organic matters compared to that of treatment-III. According to Huet (1979), the colonies of Tubifex tubifex reproduced in the mud rich organic matter. In the present study, although the availability of organic matter in treatment-I was the highest among those of treatment-II and treatment-III, the production in treatment-I $\left(371.40 \pm 18.04 \mathrm{mg} \mathrm{cm}^{-2}\right)$ was lower than that of treatment-II $\left(488.94 \pm 5.60 \mathrm{mg} \mathrm{cm}^{-2}\right)$ and treatment-III $\left(335.37 \pm 17.19 \mathrm{mg} \mathrm{cm}^{-2}\right)$. The low production in treatment-I may be due to the scarcity of dissolved oxygen created by higher decomposition of organic matter. On the other hand, treatment-III showed the least production indicating the absence of required amount of organic matter due to longer gap of media application. So, it is inferred that the media inoculation at 10 days interval is better than that of 6 days interval in terms of production. Treatment-II is also more suitable in terms of economic consideration as it reduced the media cost compared to treatment-I maintaining the comparable production. 

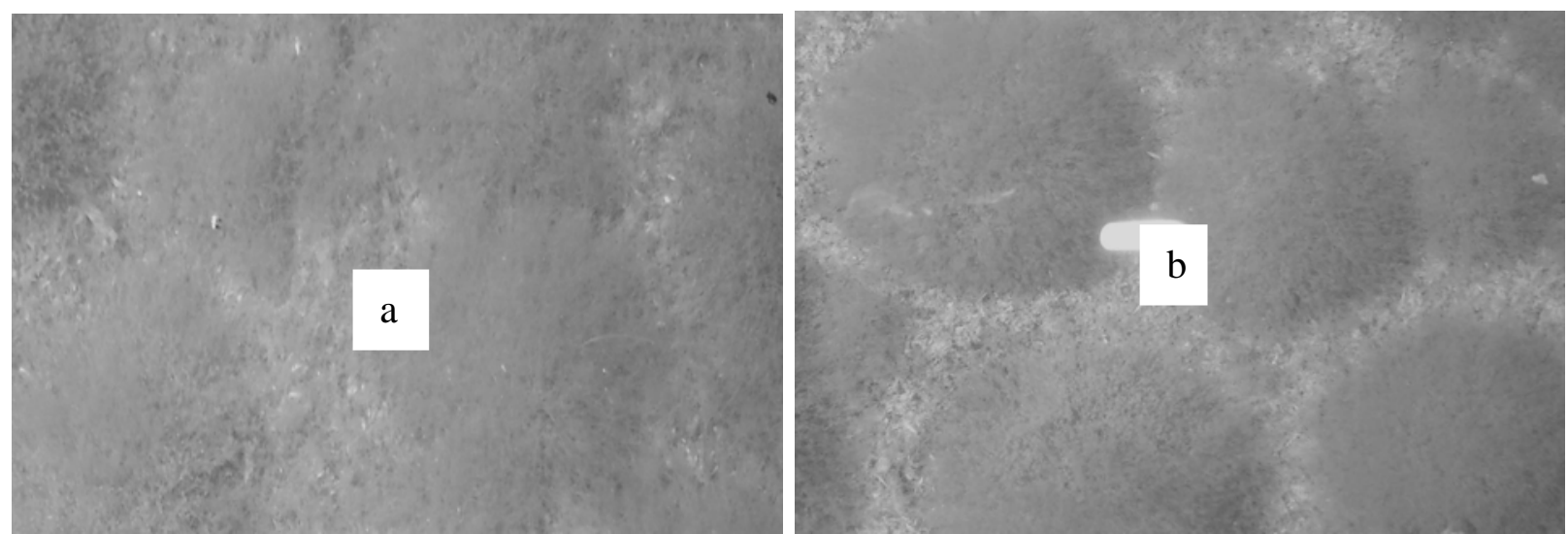

Fig. 1. Colony of Tubificid worms at a) $50^{\text {th }}$ day and b) $70^{\text {th }}$ day of culture period.

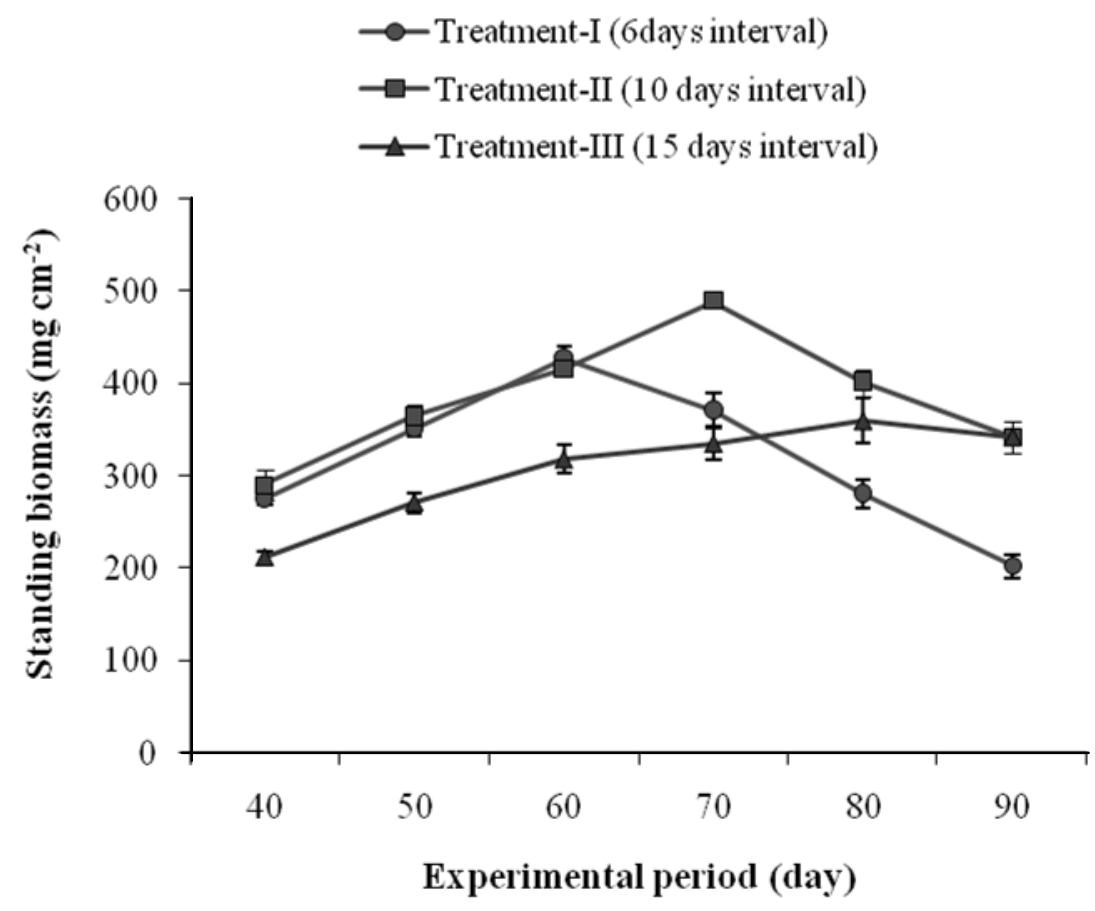

Fig. 2. Standing biomass $\left(\mathrm{mg} \mathrm{cm}^{-2}\right)$ of Tubificid worms at three different intervals $(6,10$ and 15 days) of media inoculation.

During the experiment temperature, dissolved oxygen and $\mathrm{pH}$ of water of the culverts were suitable ranging from 24.3 to $26.8^{\circ} \mathrm{C}, 7.1$ to $7.4 \mathrm{ppm}$ and 7.1 to 7.3 respectively.

\section{Conclusion}

Although the production of Tubificid worms is increased with congenial water temperature, dissolved oxygen, $\mathrm{pH}$ and water flow rate, suitable media and appropriate interval of media application to the culture system have substantial impact on the production of the worms. 


\section{References}

Ahamed, M.T. and Mollah, M.F.A. 1992. Effects of various levels of wheat bran and mustard oil cake in the culture media on Tubificid production. Aquaculture, 107: 107-113.

Alam, M.S. and Mollah, M.F.A. 1988. Formulation of an artificial dry feed for primary nursing of catfish (Clarias batrachus L) larvae. Bangladesh J. Fish., 11(1): 71-75.

Barnes, R.D. 1966. Invertebrate Zoology. W.B. Saunders Company, Philadelphia, London. 362 pp.

Buddington, P.K. and Doroshov, S.J. 1984. Feeding trials with hatchery produced white sturgeon (Acipenser transmontanus). Aquaculture, 36: 237-243.

Davis, J.R. 1982. New records of aquatic oligochaeta from Texas, with observation on their ecolological characteristics. Hydrobiologia, 96: 15-29.

Giere, O. and Pfannkuche, O. 1982. Biology and ecology of marine oligochaete, a review. In: M. Barnes (ed.), Oceanogr. Mar. Biol., Aberdeen University Press, pp 173-308.

Huet, M. 1979. Text book of culture, breeding and cultivation of fish. Fishing News Ltd., England. 436 pp.

Jordan, E.L. and Verma, R.S. 1978. Invertebrate Zoology. S. Chand and Company Ltd., Ram Nagar, New Dehli. 1018 pp.

Li RenXi. 2001. Studies on the growth and reproduction of Tubifex tubifex Muller. Acta Hydrobiol. Sinica, 25(1): 14-20.

Lietz, D.M. 1987. Potential for aquatic oligochaetes as live food in commercial aquaculture. Hydrobiologia, 155: 309-310.

Marian, M.P. and Pandian, T.J. 1984. Culture and harvesting techniques of Tubifex tubifex. Aquaculture, 42: 303-315.

Marian, M.P., Chandran, S. and Pandian, T.J. 1989. A rack culture system for Tubifex tubifex. Aquacult. Eng., 8: 329-337.

Mellanby, H. 1953. Animal life in freshwater. Methuen and Company Ltd., London. 296 pp.

Mollah, M.F.A. 1991. Culture feasibility of African catfish (Clarias gariepinus) in Bangladesh. Bangladesh J. Fish., 14: 87-89.

Mollah, M.F.A. and Hossain, M. 1995. Determination of suitable interval of media application for tubificid production. Indian J. Fish., 42(3): 48-51.

Mollah, M.F.A. and Tan, E.S.P. 1982. Effects of feeding frequency on the growth and survival of catfish (Clarias macrocephalus Gunther) larvae. Indian J. Fish., 29(1\&2): 1-7.

Mollah, M.F.A., Mamun, M.S.A., Sarowar M.N. and Roy, A. 2009. Effects of stocking density on the growth and breeding performance of broodfish and larval growth and survival of shol, Channa striatus (Bloch). J. Bangladesh Agril. Univ., 7(2): 425-430.

Phillips, G.R. and Buhler, D.R. 1979. Influences of dieldrin on the growth and body composition of fingerling of rainbow trout (Salmo gairdneri) fed Oregon moist pellets or Tubificid worms (Tubifex sp.). J. Fish. Res., Board Canada, 36: 77-80.

Poddubnaya, T.L. 1980. Life cycle of mass species of Tubificidae (Oligochaeta). In: Aquatic Oligochaete Biology (ed. R.O. Brinkhurst and D.G. Cook), pp 172-111. Plenum Press, New York. 